\author{
ElżBieta Pyza, Milena Damulewicz \\ Zakład Biologii i Obrazowania Komórki \\ Instytut Zoologii i Badań Biomedycznych \\ Uniwersytet Jagielloński \\ Gronostajowa 9, Kraków \\ E-mail: elzbieta.pyza@uj.edu.pl \\ milena.damulewicz@uj.edu.pl
}

\title{
MECHANIZMY REGULACJI SNU U DROSOPHILA MELANOGASTER
}

Sen jest okresem braku intensywnej aktywności motorycznej, podczas którego zachodzą istotne procesy w mózgu, dzięki blokadzie większości bodźców sensorycznych, które docieraja do mózgu podczas czuwania. Proces snu jest niezbędny do prawidłowego funkcjonowania organizmu, zarówno człowieka, jak i zwierząt, w tym bezkręgowców, i nie może zostać zastapiony zwykłym odpoczynkiem, czyli stanem bezczynności z zachowaniem świadomości (HENDRICKS i współaut. 2000, HUBER i współaut. 2004). Mechanizm snu został dobrze poznany u wywilżny octówki (Drosophila melanogaster), zwanej popularnie muszka owocowa, która jest powszechnie wykorzystywanym modelem zwierzęcym $\mathrm{w}$ badaniach genetycznych, neurobiologicznych, fizjologicznych, chronobiologicznych i innych.

Sen jest regulowany przez dwa odrebne mechanizmy: zegar okołodobowy (ang. circadian clock) oraz proces homeostatyczny, czyli zapotrzebowanie na sen po okresie dłuższego czuwania (DEBOER 2013). Zegar okołodobowy wyznacza dobowy cykl snu i czuwania oraz jest uniwersalnym mechanizmem regulujacym rytmiczne procesy zachodzace na poziomie komórkowym, tkankowym, narzadowym i organizmalnym. Regulacja homeostatyczna $z$ kolei reguluje długość snu, zwłaszcza po okresie deprywacji.

\section{RYTMY I ZEGARY OKOŁODOBOWE}

Zegar okołodobowy jest zbiorem komórek, tzw. oscylatorów, które charakteryzuja się rytmiczna ekspresja genów zegara. Komórki te można podzielić na (i) zegar nadrzędny - neurony zlokalizowane w mózgu, które generuja samopodtrzymujące się oscylacje, oraz (ii) zegary peryferyczne, do których należa niektóre komórki glejowe, neurony $\mathrm{w}$ narządach zmysłów oraz komórki zlokalizowane w różnych tkankach i narzadach całego ciała. Oscylacje zegarów peryferycznych zanikaja, jeżeli nie sa podtrzymywane przez zegar nadrzędny albo przez tzw. dawców czasu (niem. Zeitgeber), czyli dobowo zmieniajace się czynniki środowiska, $\mathrm{z}$ których najważniejszym jest światło. Wszystkie oscylatory charakteryzuja się rytmiczna ekspresja genów zegara, które razem $z$ kodowanymi przez nie białkami stanowia molekularny mechanizm okołodobowego zegara biologicznego. Zegar okołodobowy jest jednym $\mathrm{Z}$ wielu zegarów biologicznych - endogennych oscylatorów, które generuja rytmy o różnym okresie. Dla przykładu, zegar okołoroczny synchronizuje procesy zmieniające się $\mathrm{w}$ ciagu roku, zwane rytmami sezonowymi, jak np. cykl rozrodu u ssaków. Jednak najczęściej badanymi procesami cyklicznymi sa rytmy dobowe w procesach życiowych wszystkich organizmów, które generowane sa przez zegar okołodobowy i synchronizowane ze zmianami zachodzacymi w środowisku zewnętrznym w ciagu 24 godz., głównie przez zmiany światła czy temperatury.

Rytmy dobowe procesów biochemicznych, fizjologicznych i behawioralnych sa endogenne, jeżeli utrzymuja się $\mathrm{w}$ stałych warunkach środowiska, co można stwierdzić w 
warunkach laboratoryjnych przy zastosowaniu stałej ciemności, temperatury, wilgotności powietrza i innych czynników środowiskowych.

Dobowe rytmy aktywności lokomotorycznej oraz snu i czuwania należą do rytmów generowanych przez zegar okołodobowy. W stałej ciemności (DD) rytmy te "dryfuja”, czyli przesuwaja się w fazie w kolejnych dobach, dlatego określane sa również jako „swobodnie biegnace" (ang. free-running), a ich okres staje się dłuższy lub krótszy od 24 godz. U człowieka rytm snu i czuwania w warunkach DD ma okres dłuższy od 24 godz., średnio ok. 25 godz., a u D. melanogaster wynosi 23,8 godz., czyli jest krótszy od 24 godz. Długość okresu rytmu w warunkach stałej ciemności jest cecha gatunkowa, przy czym okres rytmu może też zmieniać się w niewielkim stopniu osobniczo. Ponadto, część osobników w każdej populacji może być nierytmiczna, zwłaszcza w warunkach laboratoryjnych co wskazuje, że rytmika procesów na poziomie genów, białek, procesów komórkowych, fizjologicznych i behawioralnych nie jest niezbędna dla przeżycia, ale zapewnia dobra kondycję, zdrowie i wpływa na długość życia. Dla przykładu brak rytmiki snu i aktywności skutkuje bezsennościa i ma poważne konsekwencje zdro- wotne, a chroniczny brak snu prowadzi do śmierci.

\section{MOLEKULARNY MECHANIZM ZEGARA OKOEODOBOWEGO DROSOPHILA MELANOGASTER}

Zegar molekularny opiera się na ekspresji kilkunastu genów, m.in.: period (per), timeless (tim), Clock (Clk), cycle (cyc), cryptochrome (cry), PAR domain protein (pdp), vrille (vri), doubletime (dbt), casein kinase 2 (ck2), jetlag (jet) i slimb. Poziom lub aktywność białek zegara zmienia się cyklicznie w ciagu doby, umożliwiając im działanie na zasadzie pętli sprzężenia zwrotnego. Pierwszymi odkrytymi u zwierzat genami zegara, były opisane u Drosophila melanogaster per i tim (KONOPKA i BENZER 1971, SeHGAl i współaut. 1994.) Geny te maja cykliczna ekspresje w komórkach oscylatorów, ulegaja jednak ekspresji również w wielu innych komórkach, gdzie moga pełnić dodatkowe funkcje, niezwiazane $z$ praca zegara biologicznego (HARDIN 2005, BENNA 2010). U D. melanogaster maksimum ekspresji per i tim przypada na koniec dnia i na poczatek nocy (HARDIN i współaut. 1990, ZENG i współaut. 1994), a zależy od dwóch czynników transkrypcyjnych CLOCK (CLK) i CYCLE (CYC), które jako he-

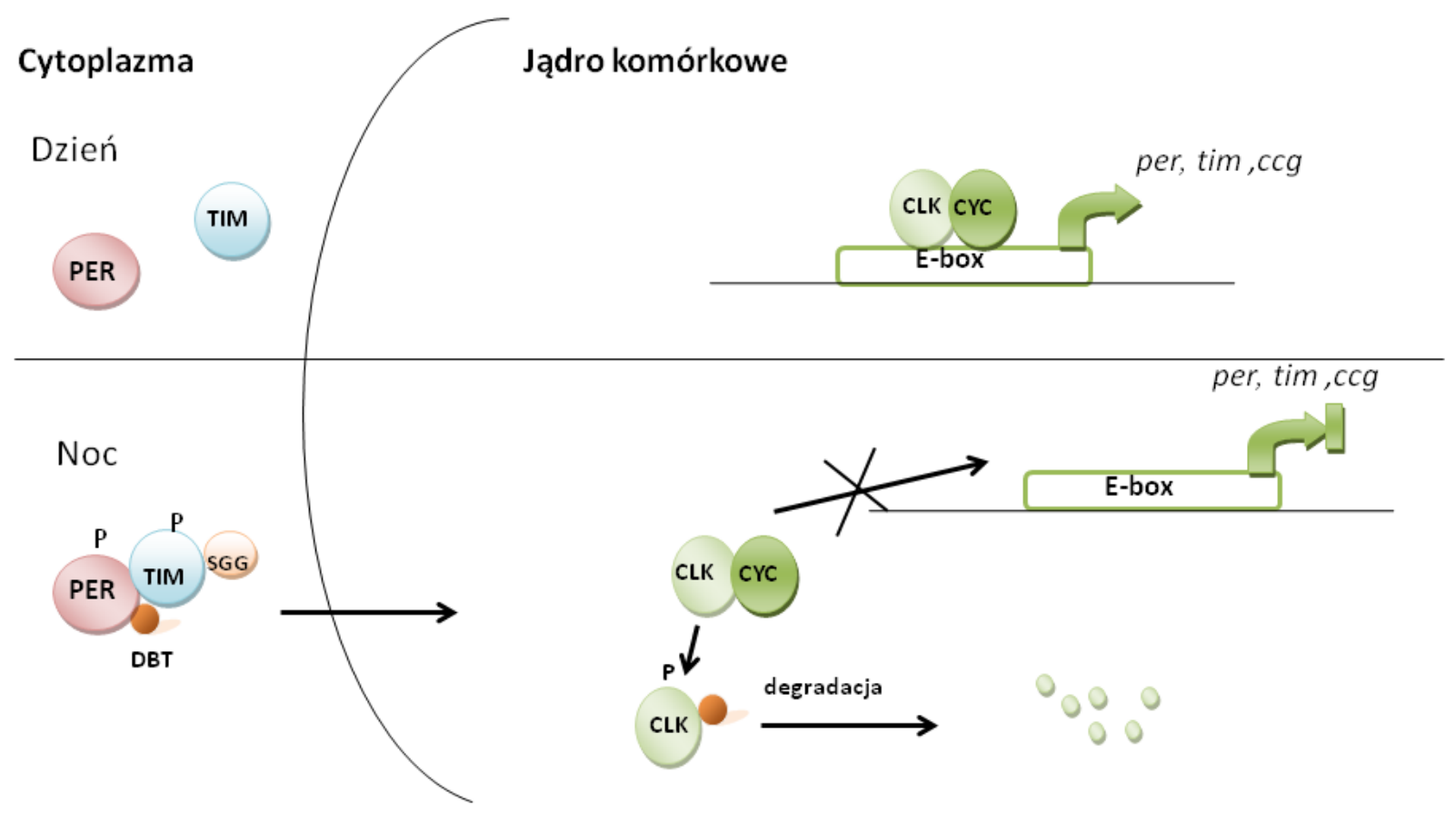

Ryc. 1 Molekularny mechanizm zegara okołodobowego Drosophila melanogaster.

Głównymi genami zegara sa per, tim, Clk i cyc, natomiast DBT i SGG fosforylując białka heterodimerów PER i TIM, uczestniczą w ich przechodzeniu do jądra komórkowego. Sam mechanizm transportu przez błonę jądrową PER $\mathrm{i}$ TIM z udziałem importyn jest nieznany. 
terodimery stymulują ich ekspresję, wiążąc się $z$ sekwencja regulatorowa, tzw. kaseta $\mathrm{E}$ (E-box), w rejonie promotora genu per i tim (Yu i współaut. 2007). Pod koniec nocy w cytoplazmie komórek zegarowych syntetyzowane sa białka PER i TIM, które także tworza heterodimery i transportowane sa do jadra komórkowego, gdzie hamując aktywność CLK i CYC, blokuja ekspresje własnych genów (LEE i współaut. 1999). W trakcie dnia białka PER i TIM ulegaja degradacji, dzięki czemu heterodimery CLK-CYC moga ponownie przyłaczyć się do E-box i aktywować transkrypcję genów. W ten sposób na zasadzie pętli sprzężenia zwrotnego ujemnego regulowana jest rytmiczna ekspresja głównych genów zegara. Cały cykl trwa 24 godz. (YU i współaut. 2006, TAYLOR i HARDIN 2008) (Ryc. 1).

Heterodimery CLK i CYC kontroluja ekspresję nie tylko genów per i tim, ale także genów kontrolowanych przez zegar okołodobowy (ang. clock-controlled genes, ccg) (YU i współaut. 2006). Oznacza to, że ekspresja tych genów jest cykliczna, poziom ich mRNA zmienia się w ciagu doby, ale nie sa one częścią molekularnego mechanizmu zegara.

Zegar molekularny może synchronizować się $z$ zewnętrznymi warunkami światła i ciemności, dzięki obecności białka KRYPTOCHROMU (CRY), które jest fotoreceptorem zegara absorbującym światło niebieskie. CRY pod wpływem światła ulega aktywacji, zmienia swoja konformację i przyłącza się do TIM (BERNDT i współaut. 2007, VANVICKLE-CHAVEZ i VAN GELDER 2007, OZTURK i współaut. 2011), który jest następnie degradowany, podobnie jak sam CRY, w wyniku ubikwitynacji przez JETLAG, element kompleksu ligazy ubikwityny E3 (HUNTER-ENSOR i współaut. 1996, LEE i współaut. 1996, MYERS i współaut. 1996, ZENG i współaut. 1996, CERIANI i współaut. 1999). Obniżony poziom TIM wpływa na stabilność PER, które $\mathrm{w}$ formie monomeru jest również degradowane przez ubikwitynację za pośrednictwem ligazy ubikwityny SLIMB. W warunkach stałego światła (LL) zależna od CRY degradacja TIM i PER następuje w sposób ciagły, w efekcie ustaja oscylacje poziomu białka i niektóre rytmy, w tym aktywność lokomotoryczna, zanikaja. Taki proces obserwowany jest m.in. u Drosophila melanogaster, ale nie jest on konserwatywny u wszystkich gatunków.

Oprócz głównej pętli ujemnego sprzężenia zwrotnego, jest jeszcze pętla dodatniego sprzężenia zwrotnego. Heterodimery CLK-CYC reguluja transkrypcję represora VRILLE (VRI) i aktywatora PDP1, które współzawodniczacc o miejsce wiazania sekwencji regulatorowej utrzymuja rytmiczna ekspresję
mRNA Clk (Yu i współaut. 2007). W przeciwieństwie do PER i TIM, poziom białek CLK i CYC nie zmienia się $w$ ciagu doby (Houl i współaut. 2006), więc oscylacje mRNA Clk maja prawdopodobnie inne funkcje niż w przypadku mRNA per i tim. Być może stabilizuja molekularny mechanizm zegara.

W skład molekularnego mechanizmu zegara wchodza również białka kontrolujace procesy potranskrypcyjne i potranslacyjne, $\mathrm{m}$. in. cykliczna fosforylację i defosforylację PER i TIM. PER jest fosforylowany przez kinazę kazeinową 1epsilon (CK1ع), DOUBLETIME (DBT) i NEMO, które kontroluja jego stabilność (KLOSS i współaut. 1998, PRICE i współaut. 1998), z kolei kinaza kazeinowa II (CKII) i SHAGGY (SGG) fosforyluja PER i TIM, biorac udział w procesie ich przechodzenia do jądra komórkowego (BAE i EDERY 2006). Wykryto jeszcze kilka innych białek, które moga kontrolować transkrypcję głównych genów zegara, formując dodatkowe pętle, takie jak CLOCKWORK ORANGE (CWO) (KADENER i współaut. 2007, LIM i współaut. 2007, MATSUMOTO i współaut. 2007, RichIER i współaut. 2008), KAYAK- $\alpha$ (LING i współaut. 2012), czy E75 (KUMAR i współaut. 2014). Z kolei regulatorami translacji PER i TIM sa białka TWENTY-FOUR (LIM i współaut. 2011) i ATAXIN-2 (LIM i ALLADA 2013).

Zegar molekularny opisany u $D$. melanogaster może być różny u innych gatunków owadów.

\section{ZEGAR OKOLODOBOWY DROSOPHILA MELANOGASTER}

U D. melanogaster zegar nadrzędny składa się ze 150 neuronów zlokalizowanych w mózgu w kilku grupach. Pomiędzy płatem wzrokowym a środkową częścia mózgu występuja dwie grupy neuronów, tzw. małe (5 neuronów o małych ciałach komórkowych) i duże (4 neurony o dużych ciałach komórkowych) neurony brzuszno-boczne (ang. small s-LNv and large 1-LNv). Neurony te, $z$ wyjątkiem jednego, tzw. piątego s-LNv, syntetyzuja neuropeptyd - czynnik rozpraszajacy pigment (ang. pigment-dispersing factor, PDF), który jest głównym neuroprzekaźnikiem zegara. Pozostałe neurony zegara to grupa neuronów brzuszno-bocznych grzbietowych (LNd), neurony boczne tylne (LPN) oraz trzy grupy neuronów grzbietowych (DN1, DN2 i DN3) (Ryc. 2). Wszystkie te grupy neuronów sa ze soba połaczone siecia wypustek, a ich wzajemne interakcje odpowiadaja za charakterystyczne cechy rytmów. Neurony s-LNv uważa się za komórki odpowiadające za poranny szczyt aktywności lokomotorycznej D. melanogaster, a neurony LNd, 5-ty s-LNv oraz 


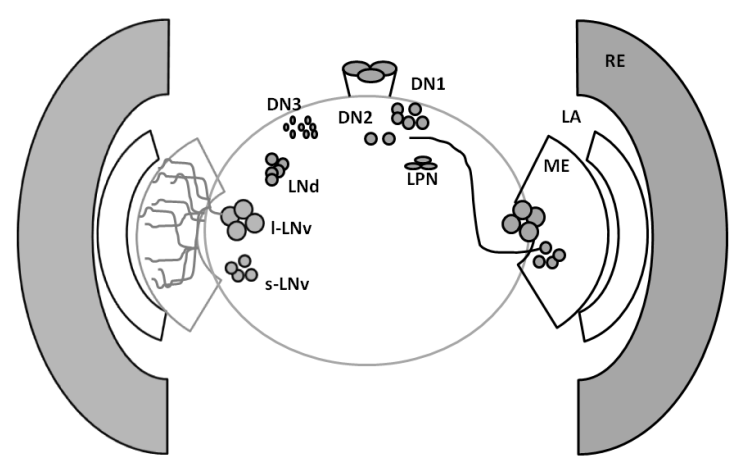

Ryc. 2 Siedem grup neuronów zegara wchodzacych w skład zegara nadrzędnego, który łącznie składa się ze 150 neuronów.

$\mathrm{RE}$ - retina, LA - lamina, ME - medulla (układ wzrokowy).

DN1 za szczyt wieczorny (GRIMA i wspó1aut. 2004, STOLERU i współaut. 2004). Te dwa szczyty charakteryzują dobowy wzór aktywności $D$. melanogaster w warunkach zmiennego oświetlenia 12 godz. światła i 12 godz. ciemności (LD12:12). Poranne zwiększenie aktywności rozpoczyna się zanim jeszcze pojawi się światło w środowisku, co określa się mianem antycypacji zmiany warunków oświetlenia i jest dowodem na obecność zegara okołodobowego (SHEEBA i współaut. 2010).

Neurony s-LNv wydają się mieć kluczowe znaczenie w regulacji dobowej rytmiki aktywności lokomotorycznej, gdyż usunięcie tej grupy komórek powoduje zanik rytmicznego behawioru. $Z$ kolei neurony grzbietowe DN1, które maja połaczenie synaptyczne $z$ s-LNv, moga być wyjściem $z$ zegara do neuronów, które nie wchodza w jego skład, ale maja wpływ na rytmikę dobowa wielu procesów, m.in. snu (CAVANAUGH i współaut. 2014).

Neurony s-LNv wykazuja zmiany morfologiczne $\mathrm{w}$ ciagu doby. Ich zakończenia aksonalne cyklicznie zmieniaja wielkość i stopień rozgałęzienia wskazując, że w ciągu doby może się zmieniać liczba synaps i neuronów postsynaptycznych, $z$ którymi kontaktuja się s-LNv (FERNANDEZ i współaut. 2008, Gorostiza i współaut. 2014). Dobowa plastyczność synaps i morfologii neuronów występuje też w innych rejonach mózgu i dotyczy neuronów innych niż zegarowe. Po raz pierwszy okołodobowa plastyczność neuronalna stwierdzono w układzie wzrokowym Drosophila i innych muchówek, co wskazuje na reorganizacje strukturalna mózgu w ciagu doby (PYZA 2013, KRZEPTOWSKI i współaut. 2018).

\section{CHARAKTERYSTYKA SNU U DROSOPHILA}

Sen u Drosophila został scharakteryzowany dopiero w 2000 r. (HENDRICKS i wspó1aut. 2000, SHAw i współaut. 2000). W badaniach tych stwierdzono, że w ciagu doby muszki pozostają dłuższy czas w bezruchu $i$ okres ten spełnia kryteria snu, ponieważ charakteryzuje się wyższym progiem pobudzenia, charakterystyczna postawa ciała oraz kompensacja po deprywacji. Pora snu regulowana jest przez zegar okołodobowy i u mutantów genów zegara, np. u mutantów per $^{0}$ sen ulega fragmentacji. Sen jest także regulowany homeostatycznie i po jego deprywacji niedobory snu wyrównywane sa przez dłuższy sen w kolejnych dobach.

Chociaż u Drosophila nie występuja fale mózgowe typowe dla stanu snu jak u ssaków, jednak zaobserwowano lokalne potencjały polowe w środkowej części mózgu (protocerebrum) oraz obniżenie aktywności neuronów w tzw. ciałach grzybkowatych, które sa ośrodkami pamięci węchowej, ale zaangażowane są także w regulację snu (NITZ i współaut. 2002, BUSHEY i współaut. 2015). W wyniku deprywacji snu, u Drosophila, podobnie jak u ssaków, obserwuje się obniżenie zdolności do uczenia się i zapamiętywania. Na sen maja też wpływ czynniki środowiskowe, socjalne, a także stan fizjologiczny organizmu, infekcje i stres.

Sen u Drosophila definiowany jest jako okres bezruchu trwajacy przynajmniej $5 \mathrm{~min}$ i dzieli się na sen nocny, który występuje w środku nocy, oraz sen dzienny, zwany drzemka albo sjesta, który występuje w trakcie dnia i jest dłuższy u samców niż u samic (HUBER i współaut. 2004). Sen, podobnie jak aktywność lokomotoryczna, mierzy się przy użyciu systemu monitorującego DAMS (ang. Drosophila Activity Monitoring System). Aktywność owadów jest rejestrowana indywidualnie dla każdego owada, który, poruszajac się w szklanej rurce, przecina wiąke podczerwieni. Każde takie przejście jest komputerowo rejestrowane i przedstawiane w postaci aktogramów. $\mathrm{Na}$ podstawie uzyskanych danych można określić okresy aktywności, bezruchu, poziom aktywności, długość sjesty i snu w nocy oraz rytmikę dobową snu i aktywności. Stosuje się również rejestrację za pomoca kamery video, dzięki czemu można precyzyjnie zaobserwować zmiany w zachowaniu owada w ciagu doby.

Badania snu na Drosophila maja tę korzyść, że rejestrację snu i jego analizę można przeprowadzić u licznych mutantów i szczepów transgenicznych, które są dostępne, lub które można wygenerować. Użycie 
specyficznych szczepów transgenicznych pozwala znakować fluorescencyjnie wybrane neurony [wprowadzenie do genomu genów innych organizmów kodujących białka fluorescencyjne, jak np. białko zielonej fluorescencji (GFP) meduzy Aquorea victoria], specyficznie je aktywować lub hamować (metoda optogenetyczna) czy usuwać (indukcja apoptozy), a także wywoływać wzrost ekspresji lub wyciszenie konkretnego genu (metoda UAS-GAL4). Dzięki zastosowaniu tych metod zidentyfikowano geny, których mutacja wpływa na długość snu lub na inne jego parametry. Na przykład, gen kodujacy kanał potasowy Shaker (CIRELLI i współaut. 2005, BusHeY i współaut. 2007) i jego modulator sleepless (KoH i współaut. 2008) odpowiedzialne sa za skrócenie snu w nocy. Ponieważ Shaker koduje napięciowo zależny kanał potasowy, który powszechnie występuje w mózgu, ma on wpływ na regulację wielu procesów. W przypadku obu genów stwierdzono, że mogą wpływać na aktywność neuronów i metabolizm neuroprzekaźników, m.in. acetylocholiny i GABA. Inne neuroprzekaźniki zaangażowane w regulację snu i aktywności to histamina, która, razem $z$ dopamina i oktopamina odpowiada za aktywność, oraz serotonina, które razem $Z$ GABA promuja sen. $Z$ kolei glutaminian ma podwójna funkcję w regulacji snu, aktywującą i hamujacą.

\section{OŚRODKI SNU U DROSOPHILA}

W mózgu Drosophila wyróżniono rejony, które maja znaczenie w regulacji snu, tzw. ośrodki snu. Sa one zlokalizowane w centralnej i grzbietowej części mózgu. Do najważniejszych struktur zaangażowanych w regulację snu należą: ciała grzybkowate (z ang. mushroom bodies, MB) oraz kompleks centralny (ang. central complex, CC), złożony $z$ ciała elipsoidalnego (ang. elipsoid body, EB) i ciała wachlarzowatego (ang. fan-shaped body, FB) (Ryc. 3).

Ciała grzybkowate tworza płaty zawierajace zarówno neurony promujące sen, jak i aktywność (JOINER i współaut. 2006, SITARAMAN i współaut. 2015, ARTIUSHIN i SEHGAL 2017). MB otrzymuje sygnały hamujace aktywność za pośrednictwem GABA i serotoniny (HAYNES i współaut. 2015, YUAN i współaut. 2006). Z kolei kompleks centralny otrzymuje hamujace sygnały $z$ komórek dopaminergicznych, które promuja aktywność (LIU i współaut. 2012, UENO i współaut. 2012, KAYSER i współaut. 2014, PIMENTEL i współaut. 2016, Ni i współaut. 2019) oraz aktywujace $z$ komórek zegara LPN (NI i współaut. 2019). Sygnały hamujace i aktywujace sa precyzyjnie integrowane i w efek-

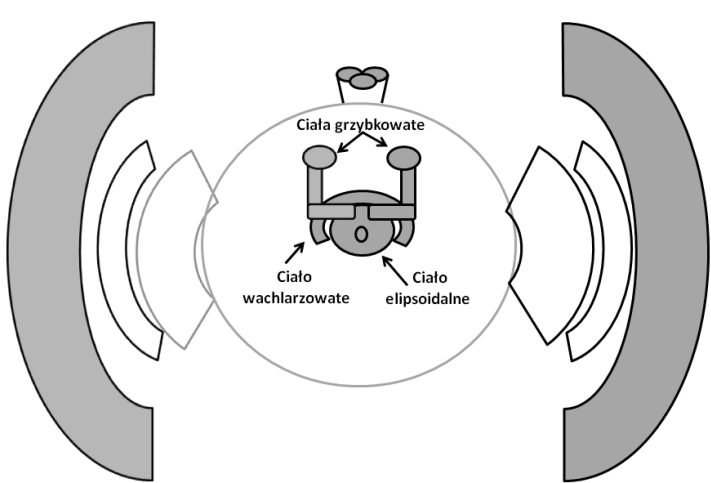

Ryc. 3 Główne ośrodki snu w mózgu Drosophila melanogaster.

cie aktywny $\mathrm{CC}$ za pośrednictwem GABA hamuje neurony oktopaminergiczne, promując sen (Ni i współaut. 2019).

Głównym neurotransmiterem regulujaccym sen i promującym aktywność Drosophila jest dopamina. Mutanty genu fumin, kodujacego transporter dopaminy, charakteryzujac się bardzo krótkim snem, prawdopodobnie w wyniku wzrostu poziomu dopaminy w całym mózgu (KuME i współaut. 2005). Metamfetamina, która jest psychostymulantem u ssaków aktywujacym układ dopaminergiczny, u Drosophila także działa pobudzajaco (ANDRETIC i współaut. 2005). O roli kompleksu centralnego w regulacji snu świadcza też eksperymenty, w których aktywowano neurony w jego części zwanej ciałem wachlarzowatym. Ta stymulacja wydłużała sen u badanych owadów, a ponieważ deprywacja snu wpływała na aktywność tych neuronów, można wnioskować, że CC odpowiada za homeostatyczną regulację snu (DONLEA i współaut. 2011). Kompleks centralny, a zwłaszcza grzbietowa część ciała wachlarzowatego, może więc pełnić centralna funkcję $\mathrm{w}$ regulacji snu jako integrator informacji dochodzących $z$ różnych rejonów mózgu, m.in. $z$ różnych grup neuronów dopaminergicznych, jak również struktury przesyłającej informacje do ośrodków docelowych, w odpowiedzi na różne bodźce regulujace sen.

Komórki produkujace drugi $z$ kluczowych neuroprzekaźników promujących aktywność - oktopamina, oprócz projekcji do ciał grzybkowatych, wysyła również zakończenia aksonalne do części kompleksu centralnego, protocerebrum, płatów wzrokowych oraz części neuroendokrynowej mózgu zwanej pars intercerebralis (PI), do neuronów produkujacych peptyd insulinopodobny. PI jest owadzim odpowiednikiem podwzgórza. Aktywacja neuronów oktopaminergicznych wywołuje wyjątkowo silny efekt hamujacy sen, który nie jest kompensowany homeostatycznie. 
Dodatkowo, w PI występuja neurony produkujace inny neuropeptyd - SIFamid, który promuje sen (FOLTENYI i współaut. 2007, PARK i współaut. 2014).

W regulacji snu ważną rolę odgrywa również inna neuroendokrynowa struktura mózgu zwana pars lateralis, gdyż obniżenie aktywności regulatorów cyklu komórkowego w neuronach tej struktury wpływało na długość snu, silnie go skracajac (RogulJA i YOUNG 2012).

Z kolei neurony histaminergiczne u Drosophila, podobnie jak u ssaków, odpowiadaja za pobudzenie (OH i współaut. 2013). Projekcje $z$ tych neuronów dochodza do rejonów brzusznego i bocznego protocerebrum mózgu Drosophila (NASSEL 1999), a antagonista receptorów histaminowych, hydroksyzyna, opóźnia sen (SHAw i współaut. 2000), jednak efekt ten zależy tylko od jednego $z$ receptorów - podjednostki kanałów chlorkowych bramkowanych histamina (HisCL1), nie jest natomiast zależny od receptorów Ort (OH i współaut. 2013). Histamina ma znaczenie w regulacji snu w dzień, gdyż obniżenie aktywności dekarboksylazy histydyny, głównego enzymu w metabolizmie histaminy wydłuża sjestę.

Serotonina, która występuje prawie we wszystkich rejonach mózgu, promuje sen, gdyż podawanie jej prekursora, 5-hydroksytryptofanu, wydłuża sen u Drosophila i odpowiada za kompensację snu po jego deprywacji (YUAN i współaut. 2006). Również GABA promuje sen, a neurony produkujące GABA unerwiaja wiele neuronów w całym mózgu. Podawanie agonistów receptora GABA-A wydłuża sen (DISSEL i współaut. 2015), a ponadto GABA odpowiedzialny jest za rozpoczęcie snu, co wskazuje na związek $z$ regulacja snu przez zegar okołodobowy. Receptory GABA-A wykryto w neuronach zegara (PARISKY i współaut. 2008), a dodatkowo wykazano, że GABA hamuje aktywność 1-LNv. Ponadto, GABA uwalniany $z$ neuronów grzbietowej części mózgu (parzyste środkowe neurony grzbietowe, DPM) hamuje ciała grzybkowate, wydłużając sen.

W regulacji snu bierze udział też glutaminian i acetylocholina. Oba te neuroprzekaźniki maja wpływ zarówno na aktywność, jak i na sen.

$\mathrm{Na}$ sen wypływają też czynniki środowiskowe i socjalne. Głód, czy inny stres silnie hamuja sen i mechanizm tego zjawiska zależy od szlaków regulujących metabolizm. Ostatnio zidentyfikowano gen translin, którego wysoka ekspresję zaobserwowano po głodzeniu muszek, natomiast jego wyciszenie przeciwdziałało hamowaniu snu przez głód (MuraKAMI i współaut. 2016). Podobny efekt zaobserwowano po obniżeniu poziomu leukokininy, peptydu syntetyzowanego przez niektóre neurony PI. Istnieje również ścisły związek pomiędzy snem a układem immunologicznym, który u Drosophila jest układem odporności wrodzonej. Brak snu powoduje wzrost poziomu czynników odpowiedzialnych za odporność, np. czynnika transkrypcyjnego RELISH (homolog NFкB u ssaków), którego poziom rośnie po deprywacji snu i który promuje sen (WILliAMs i współaut. 2007).

\section{REGULACJA SNU PRZEZ ZEGAR}

Zegar okołodobowy wyznacza zarówno porę sjesty, jak i snu w nocy. W tej regulacji snu przez zegar kluczowe znaczenie maja neurony zegara $1-\mathrm{LNv}$, gdyż ich aktywność elektryczna zmienia się w ciagu doby, a manipulacje wywołujace zmiany aktywności, zwłaszcza w nocy, wpływaja na sen i aktywność (CAO i NITABACH 2008; PARISKY i współaut. 2008; SHANG i współaut. 2008; SHEEBA i współaut. 2008a, b; LIU i ZHAO 2014). Ważna rolę $\mathrm{w}$ regulacji snu odgrywa neuropeptyd PDF, gdyż owady $z$ mutacją Pdfo i mutacja receptora Pdfr wykazywały zwiększony poziom snu w trakcie dnia (CHUNG i współaut. 2009), natomiast nadekspresja Pdfr skracała sjestę (POTDAR i SHEEBA 2018). Neurony s-LNv reguluja sen za pomoca PDF, który stymuluje aktywność neuronów w protocerebrum, wydzielajacych neuropeptyd allatostatynę A (CHEN i współaut. 2016) oraz za pomoca sNPF (ang. short Neuropeptide F), który reguluje prace $1-\mathrm{LNv}$ i odpowiada za stymulację snu w trakcie nocy (SHANG i współaut. 2013). Neurony DN1 z kolei dzielą się na populację promująca sen (a-DN1p) i promujaca aktywność (vs-DN1p) (GUO i współaut. 2018, LAMAZE i współaut. 2018).

Geny zegara, które sa aktywne o różnych porach doby; per i tim na końcu dnia i na poczatku nocy, a Clk i cyc na początku dnia, wpływaja bezpośrednio na sen, ponieważ zaobserwowano, że u mutantów $C l k$ i cyc sen wydłużał się, natomiast u mutantów per i tim skracał (LIU i wsp. 2014).

\section{ROLA KOMÓREK GLEJOWYCH W REGULACJI SNU}

Komórki glejowe przez długi czas były traktowane jako dodatkowe elementy układu nerwowego wspomagające neurony, zarówno w czasie rozwoju układu nerwowego, jak również w dorosłym mózgu, jako komórki odżywiajace neurony i usuwajace zbędne produkty. Obecnie wiadomo, że komórki glejowe pełnia kluczową rolę $\mathrm{w}$ wielu procesach w układzie nerwowym, a ich liczba w mózgu rośnie w rozwoju ewolucyjnym układu nerwowego wraz ze stopniem komplikacji 
mózgu. U D. melanogaster jest ich mniej niż neuronów w mózgu, ale u ssaków ich liczba przewyższa liczbę neuronów. Wśród komórek glejowych, zarówno u kręgowców, jak i bezkręgowców, można wyróżnić kilka typów wyspecjalizowanych w różnych funkcjach. Maja one również swój udział w regulacji rytmów okołodobowych, a te które zaangażowane sa $\mathrm{w}$ ten proces, wykazuja cykliczna ekspresje genów zegara i zwane sa oscylatorami glejowymi. Po zablokowaniu funkcji wszystkich neuronów zegara, oscylatory glejowe moga utrzymać słaby rytm aktywności lokomotorycznej (EWER i współaut. 1992).

Nasze badania wykazały, że komórki glejowe aktywne sa w nocy i moga regulować aktywność neuronów w całym mózgu, również odpowiedzialnych za różne funkcje, m.in. sen (PYZA i GÓRSKA-ANDRZEJAK 2004, WALKOWICZ i współaut. 2017). Kluczową rolę w tym procesie odgrywaja oscylatory glejowe, które synchronizowane sa przez zegar nadrzędny oraz dobowe zmiany światła. W komórkach glejowych, podobnie jak w neuronach, występuje rytmika ekspresji wielu genów, a także dobowe zmiany poziomu białek, np. podjednostki regulatorowej a pompy sodowo-potasowej, czy enzymów odpowiedzialnych za metabolizm neuroprzekaźników (GÓRSKA-ANDRZEJAK i współaut. 2009; DAMULEWICZ i współaut. 2013, 2015).

Komórki glejowe w mózgu Drosophila dziela się na kilka głównych typów: 1) glej powierzchniowy (perineurium i subperineurium), który otacza mózg i stanowi barierę hemolimfa-mózg, 2) glej korowy, 3) glej neuropilu, w którego skład wchodza komórki podobne do astrocytów (ang. astrocyte-like glial cells, AlGL) i komórki występujace na powierzchni neuropilu (ang. ensheathing glia, EnGl) oraz 4) glej peryferyjny okrywajacy aksony neuronów sensorycznych i motorycznych. Oprócz pełnienia różnych funkcji, komórki glejowe - oscylatory wykazuja też różny poziom białka PER. Najwyższy poziom zaobserwowano w komórkach glejowych sasiadujacych $z$ zakończeniami neuronów zegara 1-LNv w układzie wzrokowym (KRZEPTOWSKI i współaut. 2018).

W komórkach glejowych w mózgu wykryto wysoki poziom czynnika neurotroficznego zwanego śródmózgowym czynnikiem wzrostu astrocytów (mesencephalic astrocyte-derived neurotrofic factor, MANF), który jest homologiem MANF obecnego w mózgu ssaków. MANF w mózgu ssaków odpowiedzialny jest m.in. za hamowanie degeneracji neuronów dopaminergicznych (LINDHOLM i SAARMA 2010, PALGI i współaut. 2009). MANF u D. melanogaster (DmMANF) wystepuje w niewielkiej ilości w neuronach (w ciałach komórkowych), natomiast jego wysoki po- ziom utrzymuje się w komórkach glejowych, zwłaszcza w AlGL i EnGL. Obniżenie lub podwyższenie poziomu DmMANF w tych komórkach glejowych zaburza sen w dzień i w nocy (WALKOWICZ i współaut. 2017). Z kolei obniżenie poziomu DmMANF we wszystkich komórkach glejowych nie tylko skraca sen w nocy, ale także długość życia muszek (WALKOWICZ i współaut. 2017). Obniżenie poziomu innych białek kluczowych dla funkcjonowania komórek glejowych również powoduje zaburzenia długości snu. Dla przykładu, wyciszenie ekspresji genu Appl, kodującego białko Amyloid Precursor Protein Like (APPL) w komórkach gleju astrocytarnego, wydłuża czas snu w nocy przez wpływ na szlak regulujacy sygnalizację glutaminergiczną (FARCA LUNA i współaut. 2017). Również obniżenie poziomu białka Eiger (EGR), będącego odpowiednikiem ssaczego TNFa, oraz jego receptora, Wengen, powoduje skrócenie czasu snu (VANDERHEYDEN i współaut. 2018).

\section{PODSUMOWANIE}

Sen u D. melanogaster wykazuje wiele podobieństw do snu ssaków, nie tylko posiada cechy typowe dla tego stanu ( $z$ wyjątkiem fal mózgowych), jak wyższa konsolidacja snu w nocy, wyższy próg pobudzenia $\mathrm{w}$ czasie snu, ale również podobne mechanizmy regulacji przez neuroprzekaźniki i ich receptory. Również substancje chemiczne promujace sen lub czuwanie działaja podobnie u ssaków i Drosophila i dotyczy to nie tylko metamfetaminy, ale również kofeiny i modafinilu. Podobna jest też funkcja snu, gdyż jego brak wywołuje zaburzenia pamięci i uczenia się. Dlatego też badania snu u muszki D. melanogaster moga przynieść nowe odkrycia dotyczace regulacji i funkcji snu na poziomie komórkowym w układzie nerwowym oraz połączeń synaptycznych pomiędzy neuronami, przy udziale komórek glejowych.

\section{Streszczenie}

Sen zarówno u Drosophila, jak i u ssaków jest regulowany przez zegar okołodobowy i procesy homeostatyczne, szczególnie po okresie jego deprywacji. Funkcja snu jest podobna u różnych organizmów, jego brak wpływa na uczenie się i pamięć, a także na procesy metaboliczne i rozwój. Główny oscylator zegara okołodobowego u muszki owocowej zlokalizowany jest w mózgu i składa się ze 150 neuronów, a niektóre $z$ nich kontaktuja się $z$ neuronami tworzacymi ośrodki snu w ciałach grzybkowatych i kompleksie centralnym mózgu. W regulacji procesu snu i czuwania kluczowa rolę odgrywaja neurotransmitery, takie jak dopamina, oktopamina, serotonina, GABA i acetylocholina. W procesach regulacji snu dużą rolę odgrywają również komórki glejowe, szczególnie te, w których zlokalizowane sa oscylatory peryferyczne. 


\section{LITERATURA}

ANDREtic R., VAN Swinderen B., GreeEnspan R. J., 2005. Dopaminergic modulation of arousal in Drosophila. Curr. Biol._15, 1165-1175.

ARTIUSHIN G., SEHGAL A., 2017. The Drosophila circuitry of sleep-wake regulation. Curr. Opin. Neurobiol. 44, 243-250.

BAE K., EDERY I., 2006. Regulating a circadian clock's period, phase and amplitude by phosphorylation: Insights from Drosophila. J. Biochem. 140, 609-617.

BENNA C., BONACCORSI S., WULBECK C., HELFRICH-FORSTER C., GATTI M., KYRIACOU C. P., Costa R., SANDRElli F., 2010. Drosophila timeless 2 is required for chromosome stability and circadian photoreception. Curr. Biol. 20, 346-352.

BERNDT A., KOTTKE T., BREITKREUZ H., DVORSKY R., Hennig S., Alexander M., Wolf E., 2007. A novel photoreaction mechanism for the circadian blue light photoreceptor Drosophila cryptochrome. J. Biol. Chem. 282, 13011-13021.

Bushey D., Huber R., TONONI G., CiRElli C., 2007. Drosophila Hyperkinetic mutants have reduced sleep and impaired memory. J. Neurosci. $27,5384-5393$.

Bushey D., Tononi G., Cirelli C., 2015. Sleepand wake-dependent changes in neuronal activity and reactivity demonstrated in fly neurons using in vivo calcium imaging. Proc. Natl. Acad. Sci. USA 112, 4785-4790

CAO G., NiTABACH M. N., 2008. Circadian control of membrane excitability in Drosophila melanogaster lateral ventral clock neurons. J. Neurosci. 28, 6493-6501.

CAVANAUgh D.J., GeRATOWSKI J.D., WOOLTORTON J. R. A., SPAETHLING J.M., HECTOR C. E. ZHENG X., Johnson E. C., EBERWINE J. H., SEHGAL A., 2014. Identification of a circadian output circuit for rest:activity rhythms in Drosophila. Cell 157, 689-701.

CERIANi M. F., Darlington T. K., Staknis D., Mas P., Petti A. A., Weitz C. J., KAY S. A., 1999. Light-dependent sequestration of TIMELESS by CRYPTOCHROME. Science 285, 553-556.

Chen J., Reiher W., Hermann-Luibl C., SEllaMi A., Cognigni P., Kondo S., Helfrich-ForSTer C., Veenstra J. A., Wegener C., 2016. Allatostatin a signalling in Drosophila regulates feeding and sleep and is modulated by PDF. PLoS Genet., doi:10.1371/journal. pgen. 1006346

Chung B. Y., Kilman V. L., Keath J. R., Pitman J. L., AlLADA R., 2009. The GABAA receptor $R D L$ acts in peptidergic PDF neurons to promote sleep in Drosophila. Curr. Biol. 19, 386390.

Cirelli C., Bushey D., Hill S., Huber R., Kreber R., GANETZKY B., TONONI G., 2005. Reduced sleep in Drosophila Shaker mutants. Nature 434, 1087-1092

DAmulewicz M., Rosato E., PyZA E., 2013. Cir cadian regulation of the $\mathrm{Na}+/ \mathrm{K}+$-ATPase alpha subunit in the visual system is mediated by the pacemaker and by retina photoreceptors in Drosophila melanogaster. PLoS One 8, e73690.

DAMULEWICZ M., ŁOBODA A., BuKOVSKA-STRAKOVA K., JózKowicz A., DULAK J., PYZA E., 2015. Clock and clock-controlled genes are different ly expressed in the retina, lamina and in selected cells of the visual system of Drosophila melanogaster. Front. Cell. Neurosci. 9, 353.
DEBOER T., 2013. Behavioral and electrophysiological correlates of sleep and sleep homeostasis. Curr. Top. Behav. Neurosci. 25, 1-24.

Dissel S., Angadi V., Kirszenblat L., Suzuki Y., Donlea J., Klose M., Koch Z., English D., WINSKY-SOMMERER R., VAN SWINDEREN B., SHAW P. J., 2015. Sleep restores behavioral plasticity to drosophila mutants. Curr. Biol. 25, 1270-1281.

Donlea J. M., Thimgan M. S., SUZUKI Y., GotTschalk L., SHAW P. J., 2011. Inducing sleep by remote control facilitates memory consolidation in Drosophila. Science. 332, 15711576.

EWER J., Frisch B., HAMBlen-COYle M. J., RosBASH M., HALL J. C., 1992. Expression of the period clock gene within different cell types in the brain of Drosophila adults and mosaic analysis of these cells' influence on circadian behavioral rhythms. J. Neurosci. 12, 3321 3349.

Farca Luna A. J., Perier M., Seugnet L., 2017. Amyloid precursor protein in Drosophila glia regulates sleep and genes involved in glutamate recycling. J. Neurosci. 37, 4289-4300.

FERNANDEZ M. P., BERNI J., CERIANI M. F., 2008. Circadian remodeling of neuronal circuits involved in rhythmic behavior. PLoS Biol. 6, 0518-0524.

FOLTENYI K., GREEENSPAN R. J., NEWPORT J. W., 2007. Activation of EGFR and ERK by rhomboid signaling regulates the consolidation and maintenance of sleep in Drosophila. Nat. Neurosci. 10, 1160-1167.

Gorostiza E. A., DePeTris-Chauvin A., FREnKel L., PIRez N., CERIANI M. F., 2014. Circadian pacemaker neurons change synaptic contacts across the day. Curr. Biol. 24, 2161-2167.

GóRSKA-ANDRZEJAK J., SAlvaterRa P. M., MEINERTZHAGEN I. A., KRZEPTOWSKI W., GÖRLICH A., PYZA E., 2009. Cyclical expression of $\mathrm{Na}^{+} /$ $K^{+}$-ATPase in the visual system of Drosophila melanogaster. J. Insect Physiol. 55, 459-468.

Grima B., CHELOT E., XIA R., ROUYeR F., 2004. Morning and evening peaks of activity rely on different clock neurons of the Drosophila brain. Nature 431, 869-873.

Guo F., Holla M., Diaz M. M., Rosbash M. 2018. A circadian output circuit controls sleepwake arousal in Drosophila. Neuron 100, 624-635.

HARDIN P. E., 2005. The circadian timekeeping system of Drosophila. Curr. Biol. 15, R714-R722.

HaRdin P. E., Hall J. C., Rosbash M., 1990. Feedback of the Drosophila period gene product on circadian cycling of its messenger RNA levels. Nature 116, 5721-5726.

Haynes P. R., Christmann B. L., Griffith L. C., 2015. A single pair of neurons links sleep to memory consolidation in Drosophila melanogaster. eLife. doi:10.7554/eLife.03868.

HENDRICKS J. C., FINN S. M., PANCKERI K. A., Chavkin J., Williams J. A., SEHGal A., PACK A. I., 2000. Rest in Drosophila is a sleep-like state. Neuron 25, 129-138.

Houl J. H., Yu W., DUdeK S. M., Hardin P. E., 2006. Drosophila CLOCK is constitutively expressed in circadian oscillator and non-oscillator cells. J. Biol. Rhythms 21, 93-103.

Huber R., Hill S. L., Holladay C., BiesiadeCKI M., Tononi G., Cirelli C., 2004. Sleep homeostasis in Drosophila melanogaster. Sleep. 27, 628-639.

HunTER-Ensor M., OUSley A., SeHGal A., 1996. Regulation of the Drosophila protein timeless 
suggests a mechanism for resetting the circadian clock by light. Cell 84, 677-685.

Joiner W. J., CROCKER A., White B. H., SEHGAL A., 2006. Sleep in Drosophila is regulated by adult mushroom bodies. Nature. 441, 757760.

Kadener S., Stoleru D., Mcdonald M,. NAWATHeAN P., RosBash M., 2007. Clockwork Orange is a transcriptional repressor and a new Drosophila circadian pacemaker component. Genes Develop. 21, 1675-1686.

KAYSER M. S., YuE Z., SEHGal A., 2014. A critical period of sleep for development of courtship circuitry and behavior in Drosophila. Science 344, 269-274.

Kloss B., Price J. L., Saez L., Blau J., RothenFLUH A., WeSLEY C. S., YOUNG M. W., 1998. The Drosophila clock gene double-time encodes a protein closely related to human casein $k i-$ nase Ic. Cell 94, 97-107.

KoH K., JoineR W. J., Wu M. N., Yue Z., SMith C. J., SEHGAL A., 2008. Identification of SLEEPLESS, a Sleep-Promoting Factor. Science $321,372-376$

KONOPKA R. J., BENZER S., 1971. Clock mutants of Drosophila melanogaster. Proc. Natl. Acad. Sci. USA 68, 2112-2116.

KRZEPTOWSKI W., WALKOWICZ L., PlONCZYNSKA A, GORSKA-ANDRZEJAK J., 2018. Different levels of expression of the clock protein PER and the glial marker REPO in ensheathing and astrocyte-like glia of the distal medulla of drosophila optic lobe. Front. Physiol., doi:10.3389/ fphys.2018.00361.

Kumar S., Chen D., Jang C., NAll A., Zheng X., SEHGAL A., 2014. An ecdysone-responsive nuclear receptor regulates circadian rhythms in Drosophila. Nat. Comm., doi:10.1038/ncomms6697

Kume K., Kume S., PARK S. K., HiRsh J., JACKSON F. R., 2005. Dopamine is a regulator of arousal in the fruit fly. J. Neurosci. 25, 7377-7384.

Lamaze A., Kratschmer P., Chen K. F., Lowe S., JEPSON J. E. C., 2018. A wake-promoting circadian output circuit in Drosophila. Curr. Biol. 28, 3098-3105.

LEE C., PARIKH V., ITSUKaichi T., BAE K, Edery I., 1996. Resetting the drosophila clock by photic regulation of PER and a PER-TIM complex. Science 271, 1740-1744.

LEE C., BAE K., EDERY I., 1999. PER and TIM inhibit the DNA binding activity of a Drosophila CLOCK-CYC/dBMAL1 heterodimer without disrupting formation of the heterodimer: a basis for circadian transcription. Mol. Cell. Biol. 19, 5316-5325.

LIM C., AALlADA R., 2013. ATAXIN-2 activates PERIOD translation to sustain circadian rhythms in Drosophila. Science 66, 129-140.

Lim C., Chung B. Y., Pitman J. L., Mcgill J. J., Pradhan S., LeE J. KeEgan K. P. Choe J., AlLADA R., 2007. Clockwork orange encodes a transcriptional repressor important for circadian-clock amplitude in Drosophila. Current Biology. 17, 1082-1089.

Lim C., LeE J., CHOI C., KIlman V. L., KIM J., PARK S. M., JANG S. K., Allada R, CHOE J., 2011. The novel gene twenty-four defines a critical translational step in the Drosophila clock. Nature 470, 399-403.

LINDHOLM P., SAARMA M., 2010. Novel CDNF/ MANF family of neurotrophic factors. Develop. Neurobiol. 70, 360-371.

LING J., DUBRUILle R., EMERY P., 2012. KAYAK-a modulates circadian transcriptional feedback loops in Drosophila pacemaker neurons. J. Neurosci. 32, 16959-16970.

LiU Q., LiU S., Kodama L., DRiscoll M. R., WU M. N., 2012. Two dopaminergic neurons signal to the dorsal fan-shaped body to promote wakefulness in Drosophila. Curr. Biol. 22, 2114-2123.

LIU Z., ZHAO Z., 2014. Effects of light interruption on sleep and viability of Drosophila melanogaster. PLoS One, doi:10.1371/journal. pone.0105678.

Matsumoto A., Ukai-Tadenuma M., Yamada R. G., HOUL J., UNo K. D., Kasukawa T., DAUWALDER B., ITOH T. Q., TAKAHASHI K., UEDA R., HARDIN P. E., TANIMURA T., UEDA H. R., 2007. A functional genomics strategy reveals clockwork orange as a transcriptional regulator in the Drosophila circadian clock. Genes Develop. 21, 1687-1700.

Murakami K., Yurgel M. E., Stahl B.A., MAseK P., Mehta A., HeidKer R., Bollinger W., GiNGRAS R. M., KIM Y. J., JA W. W., SUTER B., DiAngelo J. R., KeEne A. C., 2016. Translin is required for metabolic regulation of sleep. Curr. Biol. 26, 972-980.

MYers M. P., WAGER-SMith K., RothenfluH-HilFIKER A., YOUNG M. W., 1996. Light-induced degradation of TIMELESS and entrainment of the Drosophila circadian clock. Science 271, 1736-1740.

NASSEL D. R., 1999. Histamine in the brain of insects: A review. Microsc. Res. Tech. 44, 121136.

Ni J. D., Gurav A. S., LiU W., Ogunmowo T. H. HACKBART H., ElsheikH A., VerdegaAl A. A., MONTELL C. 2019. Differential regulation of the drosophila sleep homeostat by circadian and arousal inputs. eLife, doi:10.7554/eLife.40487.

Nitz D. A., VAN SWINDEREN B., TONONI G., GREENSPAN R. J., 2002. Electrophysiological correlates of rest and activity in Drosophila melanogaster. Curr. Biol. 12, 1934-1940.

OH Y., JANG D., SONN J. Y., CHOE J., 2013. Histamine-HisCl1 Receptor Axis Regulates Wake-Promoting Signals in Drosophila melanogaster. PLoS One, doi:10.1371/journal. pone.0068269.

Ozturk N., Selby C. P., Annayev Y., Zhong D., SANCAR A., 2011. Reaction mechanism of Drosophila cryptochrome. Proc. Natl. Acad. Sci. USA 108, 516-521.

Palgi M., Lindstrom R., Peranen J., Piepponen T. P., SAARMA M., HEINO T. I., 2009. Evidence that DmMANF is an invertebrate neurotrophic factor supporting dopaminergic neurons. Proc. Natl. Acad. Sci. USA 106, 2429-2434.

PARISKY K. M., Agosto J., PUlver S. R., Shang Y., KuKlin E., Hodge J. J. L., Kang K., LiU X., GaRrity P. A., Rosbash M., GRIFFITH L. C., 2008. PDF Cells are a GABA-responsive wake-promoting component of the Drosophila sleep circuit. Neuron 60, 672-682.

Park S., Alfa R. W., TOPper S. M., Kim G. E. S., KoCKel L., KIM S. K., 2014. A genetic strategy to measure circulating Drosophila insulin reveals genes regulating insulin production and secretion. PLoS Genet., doi:10.1371/journal.pgen.1004555.

Pimentel D., Donlea J. M., TAlbot C. B., Song S. M., Thurston A. J. F. , MiesenBock G., 2016. Operation of a homeostatic sleep switch. Nature 536, 333-337.

POTDAR S., SHEEBA V., 2018. Wakefulness is promoted during day time by PDFR signalling to dopaminergic neurons in Drosophila 
melanogaster. eNeuro, doi:10.1523/ENEURO.0129-18.2018.

PRICE J. L., BLAU J., ROTHENFLUH A., ABODEELY M., KLoss B., Young M. W., 1998. Double-time is a novel Drosophila clock gene that regulates period protein accumulation. Cell 94, 83-95.

PYZA E. M., 2013. Plasticity in invertebrate sensory systems. Front Physiol. 4, doi: 10.3389/ fphys.2013.00226..

PYZA E., GÓRSKA-ANDRZEJAK J., 2004. Involvement of glial cells in rhythmic size changes in neurons of the housefly's visual system. J. Neurobiol. 59, 205-215.

RichiER B. Michard-VANHEE C. LAMOROUX A. PAPIN C., ROUYER F., 2008. The clockwork or ange Drosophila protein functions as both an activator and a repressor of clock gene expression. J. Biol. Rhythms 23, 103-116.

RogulJA D., Young M. W., 2012. Control of sleep by cyclin $A$ and its regulator. Science. 335, $1617-1621$.

Sehgal A., PRICE J. L., Man B., Young M. W. 1994. Loss of circadian behavioral rhythms and per RNA oscillations in the Drosophila mutant timeless. Science 263, 1603-1606.

Shang Y., GRIfFITH L. C., ROSBASH M., 2008. Light-arousal and circadian photoreception circuits intersect at the large PDF cells of the Drosophila brain. Proc. Natl. Acad. Sci. USA 105, 19587-19594.

Shang Y., Donelson N. C., Vecsey C. G., Guo F., Rosbash M., Griffith L. C., 2013. Short neuropeptide $f$ is a sleep-promoting inhibitory modulator. Neuron. 209, 815-828.

SHAW P. J., CIRELli C., GREENSPAN R. J., TONONI G., CAMPBell S. S., TOBleR I., ZEPELIN H., RECHTSCHAFFEN A., TOBLER I.,STALDER J., TOBler I., NEUNER-JEHLE M., KAISER W., wspólaut., 2000. Correlates of sleep and waking in Drosophila melanogaster. Science 287, 1834-1837.

Sheeba V., Fogle K. J., Kaneko M., Rashid S., CHOU Y. T., SHARMA V. K., Holmes T. C., 2008a. Large ventral lateral neurons modulate arousal and sleep in Drosophila. Curr. Biol. $18,1537-1545$.

Sheeba V., Gu H., Sharma V. K., O’Dowd D. K., Holmes T. C., 2008b. Circadian- and light-dependent regulation of resting membrane potential and spontaneous action potential firing of Drosophila circadian pacemaker neurons. J. Neurophysiol. 99, 976-988.

SheebA V., Fogle K. J., Holmes T. C., 2010. Persistence of morning anticipation behavior and high amplitude morning startle response following functional loss of small ventral lateral neurons in drosophila. PLoS One 5, doi:10.1371/journal.pone.0011628.
SitARAman D., Aso Y., Rubin G. M., NitABACH M. N., 2015. Control of sleep by dopaminergic inputs to the drosophila mushroom body. Front. Neural Circuits, doi:10.3389/fncir.2015.00073.

Stoleru D., Peng Y., Agosto J., Rosbash M., 2004. Coupled oscillators control morning and evening locomotor behaviour of Drosophila. Nature. 431, 862-868.

TAYLOR P., HARDIN P. E., 2008. Rhythmic E-box binding by CLK-CYC controls daily cycles in per and tim transcription and chromatin modifications. Mol. Cell. Biol. 28, 4642-4652.

Ueno T., TOMita J., TANimoto H., ENDO K., ITO K., KumE S., KumE K., 2012. Identification of a dopamine pathway that regulates sleep and arousal in Drosophila. Nat. Neurosci. 15, 1516-1523.

VAN GELDER R. N., 2002. Tales from the crypt(ochromes). J. Biol. Rhythms 17, 110-120.

VANDERHEYDEN W. M., GOODMAN A. G., TAYLOR R. H., FRANK M. G., VAN DONGEN H. P. A., GeRSTNER J. R., 2018. Astrocyte expression of the Drosophila TNF-alpha homologue, Eiger, regulates sleep in flies. PLoS Genet., doi:10.1371/ journal.pgen. 1007724

VANVICKLE-CHAVEZ S. J., VAN GELDER R. N., 2007. Action spectrum of Drosophila cryptochrome. J. Biol. Chem. 282, 10561-10566.

WALKOWICZ L., KIJAK E., KRZEPTOWSKI W., GORSKA-ANDRZEJAK J., STRATOULIAS V., Woznicka O., Chwastek E., Heino T. I., Pyza E. M., 2017. Downregulation of DMMANF in glial cells results in neurodegeneration and affects sleep and lifespan in Drosophila melanogaster. Front. Neurosci., doi:10.3389/ fnins.2017.00610.

WILLIAMS J. A., SATHYANARAYANAN S., HENDRICKS J. C., SEHGAL A., 2007. Interaction between sleep and the immune response in Drosophila: A role for the $N F \kappa B$ relish. Sleep 30, 389-400.

YU W., ZHENG H., HOUL J. H., DAUWALDER B., HARDIN P. E., 2006. PER-dependent rhythms in CLK phosphorylation and E-box binding regulate circadian transcription. Genes Develop. 20, 723-733.

Yu Y., DONG W., Altimus C., TANG X., GRIFFith J., Morello M., DudeK L., ARNold J., SchuTTLER H. B., 2007. A genetic network for the clock of Neurospora crassa. Proc. Natl. Acad. Sci. USA 104, 2809-2814.

YUAN Q., JOINER W. J., SEHGAL A., 2006. A sleep-promoting role for the Drosophila serotonin receptor 1A. Curr. Biol. 16, 1051-1062.

ZENG H., HaRdin P. E., Rosbash M., 1994. Constitutive overexpression of the Drosophila period protein inhibits period $m R N A$ cycling. EMBO J. 13, 3590-3598. 
KOSMOS Vol. 69, 3, 403-413, 2020

\section{Elżbieta Pyza, Milena Damulewicz}

Department of Cell Biology and Imaging, Institute of Zoology and Biomedical Research, Jagiellonian University, 9 Gronostajowa Str., Kraków,E-mail: elzbieta.pyza@uj.edu.pl,milena.damulewicz@uj.edu.pl

\section{MECHANISMS OF SLEEP REGULATION IN DROSOPHILA MELANOGASTER}

\section{Summary}

In both Drosophila and mammals, sleep is regulated by the circadian clock and homeostatic processes, especially after deprivation. Its function is also similar in different organisms, since the lack of sleep affects learning and memory but also development and metabolic processes. The circadian clock, the pacemaker in the brain, is composed of 150 neurons and some of them contact sleep regulating neurons located in mushroom bodies, a center of olfaction memory, and in the central complex. Wake or sleep promoting neurons are regulated by several neurotransmitters, and among them dopamine and octopamine promote wake, serotonin and GABA promote sleep, while glutamine and acetylcholine have dual function. Besides neurons, also glial cells are important in sleep regulation, especially those expressing clock genes, so-called glial oscillators.

Key words: circadian clock, glial cells, homeostatic regulation of sleep 